\title{
HCV INFECTION AND FREQUENCY OF DISTRIBUTION.
}

\footnotetext{
1. M.Sc, M.Phil, PhD Associate Professor Department of Biochemistry IMC, Faisalabad

2. PhD scholar Department of Biochemistry UAF.

3. M.Phil

Department of Biochemistry UAF.

4. PhD.

Professor

Department of Biochemistry UAF.
}

Correspondence Address: Dr. Nighat Aslam

Department of Biochemistry IMC, Faisalabad.

nighatnaeem@gmail.com

Article received on: 13/07/2018 Accepted for publication: 22/05/2019

Received after proof reading: $30 / 09 / 2019$

\begin{abstract}
Nighat Aslam ${ }^{1}$, Khalid Nadeem Asif ${ }^{2}$, Sadia Zafar ${ }^{3}$, Amer Jamil ${ }^{4}$
ABSTRACT... Worldwide, an estimated 130-170 million people are infected with Hepatitis C. The geographic distribution of $\mathrm{HCV}$ infection is highly variable between and within countries. To start the antiviral therapy, it is necessary to find the genotype in order to get better forecast about observed duration of treatment. This also provides the load of virus. Treatments for patients with chronic HCV infection have recently advanced with newly licensed antivirals, which specifically target HCV. Objectives: To find out the prevalence of HCV in Faisalabad region of Pakistan and to evaluate the frequency distribution of various HCV genotypes among those with HCV infection. Study Design: Descriptive cross sectional. Settings: Blood samples were received from Biotech Lab, Pinum cancer hospital Faisal Laboratory, Alshafa lab Jaranwala, Mehran Lab, Samundari, Rashid Lab, Shahkot and Molecular care, Human Molecular Diagnostic Department of Biochemistry University of Agriculture Faisalabad. Period: May 2016 to April 2017. Material and Methods: The data for this study included a total of 382 anti-HCV positive blood sera samples, collected from different collection centers. Nested reverse transcription (RT) PCR was done for the qualitative detection of HCV. RNA using primers that correspond to the relatively conservative 5'UTR noncoding region of the highly mutable HCV were used. Data was analysed using the descriptive statistics. Results: 233 samples were found to be confirm positive for HCV RNA by qualitative PCR. 98 (42\%) were females and 135 (58\%) were males. The age-group of 36-45 years bear the largest number of HCV patients $(37.08 \%)$ and smallest number of patients was in the $56-65$ years age-group. A total of $87.55 \%$ patients belong were below 45 years of age. The genotype 3a, 135 (77\%) was the most prevalent form of all HCV genotypes in Faisalabad. A peripheral area of Faisalabad almost same distribution has been observed. The other strains detected were $2 \mathrm{a}, 29 \%$ 3b $11 \%$ were males and $5 \%$ were female), and none of the patient was detected with $2 \mathrm{~b}, 4 \mathrm{a}, 5 \mathrm{a}$ and $6 \mathrm{a}$ genotype of $\mathrm{HCV}$. Conclusion: This data analysis shows that there is no specific relationship of age-groups or genders in case of prevalence of different HCV Genotypes but female patients were found to have higher frequency of HCV infection.
\end{abstract}

Key words: $\quad$ HCV Infection, Frequency in Faisalabad, HCV Genotype, RT-PCR.

Article Citation: Aslam N, Asif KN, Zafar S, Jamil A. HCV infection and frequency of distribution. Professional Med J 2019; 26(10):1770-1775.

DOI: 10.29309/TPMJ/2019.26.10.4139

\section{INTRODUCTION}

HCVhassevengenotypesand can be differentiated on the basis of genetic makeup. ${ }^{1}$ Among all seven genotypes, the genotype 1 is the major and very common genotype worldwide especially in the USA and Europe and it covers $46.2 \%$ of all HCV infected population of the world. ${ }^{2} \mathrm{HCV}$ genotype 3 is the main genotype found in HCV patients of Pakistan ${ }^{3}$ and is covering $30 \%$ of world wide $\mathrm{HCV}$ infected population. ${ }^{2,3}$ Genotype 3 is considered to be widely prevalent in Pakistan. ${ }^{4}$ Genotype 5 is the prevalent genotype in South Africa while 6 is dominant in Hong Kong. ${ }^{5}$
Virus that causes Hepatitis $C$ was discovered as non-A non-B hepatitis virus. ${ }^{6}$ The Hepatitis $C$ virus (HCV) with a total genome of 9.5 kilo base $(\mathrm{Kb})$ belongs to genus Hepacivirus. It is a positive single stranded RNA virus and HCV is enveloped by two types of glycoproteins E1 and E2. ${ }^{7,8}$

Hepatitis C virus (HCV) mainly attacks the hepatocytes (liver cells) where it multiplies (replicates) and kill liver cells and thus HCV positive patients may develop chronic liver disease and hepatocellular carcinoma (HCC). ${ }^{9}$ 
In 60 to $80 \%$ of HCV positive patients, the acute state of hepatitis infection changes to chronic infection and then to hepatic steatosis. ${ }^{10}$ Changes in lipid metabolism associated with HCV leads to steatosis and among all genotypes of HCV, steatosis is frequently found in patients who are infected by HCV genotype 3. ${ }^{11,12}$ Hepatic steatoses is a severe condition of fluid accumulation in the hepatocytes, and this fluid accumulation is the major indication of cirrhosis development. ${ }^{13}$ Cirrhosis is a condition in which liver does not work properly and fibrosis starts in liver cells which leads to hepatocellular carcinoma. Hepatocellular carcinoma associated with Hepatitis B or Hepatitis $\mathrm{C}$ is one of the common malignancy with estimated annual cases from 500000 to 1000000 annually. ${ }^{14}$ Over the last 20 years the ratio of HCV mortality has been increasing continuously. About 60\% of these patients have the genotype 1 strain of Hepatitis $\mathrm{C}$ virus. ${ }^{15}$

To start the antiviral therapy, it is necessary to find the genotype in order to get better forecast about observed duration of treatment. This also provides the load of virus. The particular advised duration of therapy regarding genotype 2 and 3 is 24 weeks and in case of genotype 1, the advised time period is 48 weeks. ${ }^{15,16}$

Liver could be a distinctive organ as a result of it's the power to regenerate that is clinically imperative as this permits the liver to repair itself particularly subsequent acute liver failure caused by factors like medication or toxins. This additionally has much entanglement for treating patients laid low with chronic liver failure. Patients will either bear a liver transplant; wherever the donor liver is split and carry to treat many patients because it is in a position to regenerate over time, or they will bear a partial hepatectomy to get rid of a part of their own liver, which can be broken or contain a tumor, and therefore the remaining liver is left to regenerate. ${ }^{17}$

Chronic liver failure is commonly occurred by recurring liver injury that induces chronic inflammation. Factors like high alcohol intake, having a liver disease or infection will cause chronic disease. Prolonged inflammation of the liver initiates pathology, the liver wound healing response, which, though reversible, causes scarring of the liver and may result in severe scarring of the liver, referred to as liver disease. Liver disease is commonly irreversible, inflicting liver failure and increasing the chance of carcinoma or cancer of the liver. At this stage of disease, though patients will bear a liver transplant or partial hepatectomy this could not continually be attainable as a result of the restricted availableness of donor organs. As a result, disease could be a major explanation for death. Moreover, infection, an outsized proportion of that is attributable to viral hepatitis virus (HCV), causes tremendous load on liver transplantation within the GB and western world. ${ }^{17}$

Treatments for patients with chronic HCV infection have recently advanced with new licenced antivirals, that particularly hit HCV. Before these new treatments, the quality treatment for $\mathrm{HCV}$ infected patients was a mixture medical aid of interferon- $\alpha$ and pegylated antiviral, that had several adverse effects. The new antivirals are being offered together medical aid with the quality treatment of interferon-a and pegylated antiviral, that not solely will increase the adverse effects however additionally will increase the price of treatment. HCV-RNA by PCR is the fastest and most informative technique for HCV detection, whereas lengthy infection duration is needed to notice virus antibodies. ${ }^{18,19}$

The viral hepatitis designation largely depends on serologic assay and HCV polymer. For the medical specialty police investigation and screening, verifying recombinant immunoblot assay and enzyme-linked-immunosorbent serologic assay area unit performed for the identification of HCV-specific antibodies. For the identification of microorganism order and confirmation of active infection, qualitative enzyme chain reaction is employed. This system is kind of effective in watching sickness activity and treatment response. ${ }^{19}$

A study conducted in Bahawalpur disclosed that other genotypes also found in many areas 
of the country beside genotypes 3 . The current project therefore was focused on as no inclusive studies have been carried out in the city of Faisalabad. Main objective of this study was to find out the prevalence of HCV in Faisalabad region of Pakistan and to evaluate the frequency distribution of various HCV genotypes among those with HCV infection.

\section{MATERIAL AND METHOD}

The data was collected from collection centres of Faisalabad. The patients were those who were admitted with liver disease. The patient's consent and the required medical and clinical information was taken at the time of data collection on a specifically designed form. For the qualitative detection of $\mathrm{HCV}$, nested reverse transcription (RT) PCR was performed. RNA primers were used for the RT PCR. These correspond to the conservative 5'UTR in the noncoding region of the highly mutable $\mathrm{HCV}^{20} \mathrm{HCV}$ viral RNA was extracted from $200 \mathrm{~L}$ of serum sample by using viral RNA extraction kit "Gene JET Viral DNA/ RNA Purification Kit, Thermo Fisher Scientific Inc. USA" as described by the protocol. In first step, RT-PCR was used to synthesized CDNA from the kit described above. Specified 5'UTR region of extracted viral RNA, were used using antisense primer. By using reverse transcriptase, dsDNA was produced. In the reaction mixture, the primers for the first round were added. With another set of primers, nested PCRs were performed. Taq polymerase enzyme was used for this purpose. Agarose gel electrophoresis was performed using $2 \%$ agarose gel. Gel was dipped in ethidium bromide solution so as to visualized under UV light. The samples were then preceded for their genotyping after confirmation of presence of HCV. For HCV genotyping, cDNA was synthesized using 100ng of RNA of HCV. Enzyme used was reverse transcriptase. Kit used was "Verso 1-Step RT-PCR Kit (Thermo Fisher Scientific Inc. USA)". The same PCR reaction mixture sample was again amplified. For this, core region and non-coding region of HCV 5'UTR were used. Two second-round multiplex PCRs were performed for nested PCR. For this purpose, two types of primers were used. Primer mixture one and primer mixture two. Mixture-1 had primers for "genotypes 1a, 1b, 1c, 3a, 3c and 4" while Mixture-2 had primers for "genotypes 2a, 2c, 3b, $5 \mathrm{a}$, and $6 \mathrm{a}$ ". The agarose gel (2\%) was used with ladder of 50bp and evaluated under UV light after dipping in solution of ethidium bromide. For each sample, PCR which was specific for detection of genotype was run.

\section{RESULTS}

The data for this study included a total of 382 antiHCV positive blood sera samples were received at Biotech Lab., Pinum Cancer Hospital Faisal Laboratory, Alshafa lab Jaranwala, Mehran Lab., Samundari., Rashid Lab., Shahkot and Molecular care, Human Molecular Diagnostic Department of Biochemistry University of Agriculture Faisalabad. Out of these samples, 233 samples were found to be confirm positive for HCV RNA by qualitative PCR. $42 \%$ were females and $58 \%$ were males. In the age-group of 36-45 years, there were the largest number of HCV patients with the percentage of 37.08 and 56-65 years have lowest percentage of $\mathrm{HCV}$ patients. A total of $87.55 \%$ patients belong were below 45 years of age (Figure-1). The genotype prevalence in our data shown in Table-I. The genotype 3a, 135 (77\%) was the most prevalent form of all HCV genotypes in Faisalabad. In peripheral areas, the same situation has been observed in the regarding the genotype prevalence. The most frequent form is $3 a, 153$ (79\%), $2 \mathrm{a}(12 \%)$ and $3 \mathrm{~b}(3 \%)$ respectively (TableII). This data shows that the age-group of 16-25, where male patients were 11 balance and female patients were 10 . Total patients were 21 in this group. as both have 30 patients. In another age group of 36-45 the number of patients was almost equal representing 29 male and 28 female (TableIII). All other age-groups, female has less number of total genotypes than the male. PCR analysis of hepatitis $\mathrm{C}$ virus for genotype of $172-\mathrm{HCV}$ positive patients was carried out. The result shows that out of 172 patients, 7 couldn't assigned any type for genotype. This could be either due to some genotypes which is still unknown or low viral load of HCV. In peripheral areas of Faisalabad almost same distribution has been observed. The other strains detected were $2 \mathrm{a}$, which has percentage of 29 , 3b strain has the percentage of 11 for males and 5 for females. None of the patient was 
detected with $2 \mathrm{~b}, 4 \mathrm{a}, 5 \mathrm{a}$ and $6 \mathrm{a}$ genotype of $\mathrm{HCV}$ (Table-III). This data analysis shows that in case of prevalence of different HCV genotypes, there is no specific relationship of age-groups or genders however female patients were found to have more rate of HCV infection.

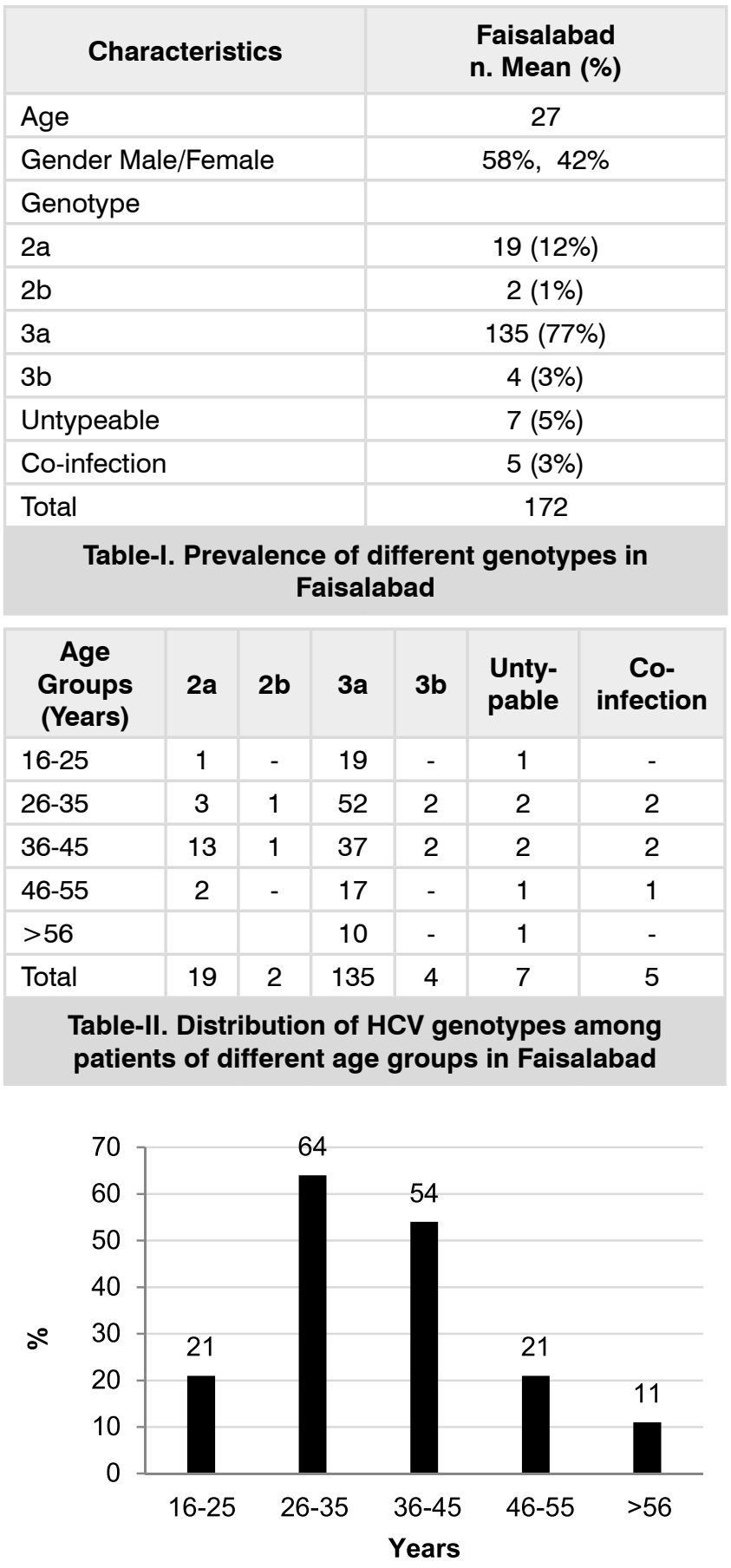

Figure-1. Age group analyses of HCV genotypes in Faisalabad

\begin{tabular}{|c|c|c|c|c|c|c|}
\hline \multicolumn{4}{|c|}{ Characteristics } & \multicolumn{3}{|c|}{$\begin{array}{l}\text { Faisalabad } \\
\text { n. Mean (\%) }\end{array}$} \\
\hline \multicolumn{4}{|l|}{ Age } & \multicolumn{3}{|c|}{25.5} \\
\hline \multicolumn{4}{|c|}{ Gender Male/Female } & \multicolumn{3}{|c|}{129 (58\%), 77 (42\%) } \\
\hline \multicolumn{7}{|c|}{ Genotype } \\
\hline \multicolumn{4}{|c|}{$2 a$} & \multicolumn{3}{|c|}{$29(12 \%)$} \\
\hline \multicolumn{4}{|l|}{$2 b$} & \multicolumn{3}{|c|}{-} \\
\hline \multicolumn{4}{|l|}{$3 a$} & \multicolumn{3}{|c|}{$153(79 \%)$} \\
\hline \multicolumn{4}{|l|}{$3 b$} & \multicolumn{3}{|c|}{$11(3 \%)$} \\
\hline \multicolumn{4}{|c|}{ Untypeable } & \multicolumn{3}{|c|}{$17(5 \%)$} \\
\hline \multicolumn{4}{|c|}{ Co-infection } & \multicolumn{3}{|c|}{$4(3 \%)$} \\
\hline \multicolumn{4}{|c|}{ Total } & \multicolumn{3}{|c|}{210} \\
\hline \multicolumn{7}{|c|}{$\begin{array}{l}\text { Table-III. Prevalence of different genotypes in } \\
\text { peripheral area of Faisalabad }\end{array}$} \\
\hline $\begin{array}{l}\text { Age } \\
\text { groups } \\
\text { (Years) }\end{array}$ & $2 a$ & $2 b$ & $3 a$ & 3b & $\begin{array}{l}\text { Unty- } \\
\text { pable }\end{array}$ & $\begin{array}{c}\text { Co- } \\
\text { infection }\end{array}$ \\
\hline $16-25$ & 1 & - & 24 & - & 1 & - \\
\hline $26-35$ & 3 & 1 & 52 & 4 & 2 & 4 \\
\hline $36-45$ & 5 & 1 & 54 & 2 & - & 2 \\
\hline $46-55$ & 2 & - & 31 & - & - & 1 \\
\hline$>56$ & & & 20 & - & - & - \\
\hline Total & 13 & 2 & 178 & 6 & 3 & 8 \\
\hline
\end{tabular}

Table-IV. Distribution of HCV genotypes among patients of different age groups in peripheral areas

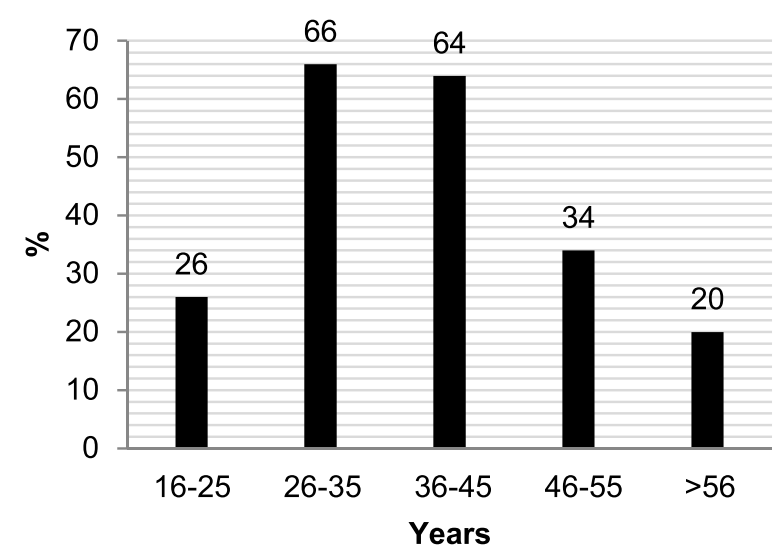

Figure-2. Age group analyses of HCV genotypes in peripheral areas

\section{DISCUSSION}

For proper management of the patients of hepatitis $\mathrm{C}$, its genotyping is very important. Determination of the HCV genotypes is of essential for the study of many aspects of HCV infection including epidemiology, pathogenesis, and its 
responsiveness to the ribavirin or interferon. Genotyping that can differentiate $1 \mathrm{a}$ and $1 \mathrm{~b}$ subtypes must be done before starting therapy. This is very important because HCV genotyping greatly depends on ribavirin dose and treatment duration. Identification of correct HCV genotype has a great influence on treatment success and patient cure. Insights into molecular epidemiology studies to know the HCV distribution across the world is also aided by genotyping. ${ }^{21}$ Finally, genotyping is also important for interpreting variants associated with resistance as some changes depending on the specific subtyping or genotyping may be common polymorphisms. ${ }^{22}$ In Pakistan, HCV is one of the major cause of early death and an important cause chronic liver disease and liver cirrhosis. About $6 \%$ of the Pakistani population is infected with $\mathrm{HCV}$. In this research, we study 382 cases of positive $\mathrm{HCV}$ antibodies having different genotypes. By analyzing on qualitative PCR, only 233 were confirmed as infected by HCV. This study also demonstrates that screening by an anti-HCV ELISA or with immuno-chromatographic test kit lack the required correction and sensitivity. So, due to higher levels of specificity and sensitivity the detection of HCV by a PCR based methods is considered as the best possible option. Like any other pathogen derived infection, HCV infection is also an example of those diseases in which direct detection of the pathogenic viral agent is required for an error-free diagnosis. ${ }^{22}$ We have analyzed the relation between occurrence of $\mathrm{HCV}$ genotypes in different genders and age groups. Our results showed that HCV frequency is nonsignificant among the different age groups. Our study showed that HCV infection is higher in males than females. These results are in consistence with the results of previously done research. Our results indicate that the in-Faisalabad region maximum patients are in the age group of $\leq 50$ and $>16$ years of age. A study done by Niu., et al, 2016 also shows the same results that $\mathrm{HCV}$ was more among the age group of 16-50 years ${ }^{23}$ but in a contradict to a study it was shows that there was a higher HCV distribution among older age group. ${ }^{24}$ We propose two reasons for these results, either the higher prevalence of $\mathrm{HCV}$ in younger age is due to an increasing awareness and early diagnosis of $\mathrm{HCV}$ or this could be due to their increased exposure to the risk factor. These factors resulted in higher reported cases specially the urban areas of Pakistan like Faisalabad. Current study shows that $2 a$ is second most prevalent genotypes among the studied individuals while genotype $3 a$ is the most frequent among the HCV carrier individuals. These results are in agreement to previously done many studies on Pakistani population. ${ }^{25}$

\section{Copyright@ 22 May, 2019.}

\section{REFERENCES}

1. Jose L W, Gutierrez, EllIman J A, Stump W B, Keller D D, Rodriguez T R. Profiles of substitutions in hepatitis $C$ virus RNA of the core, alternate reading frame, and NS2 coding regions. RNA. 2005; 8: 557-571.

2. Franciscus, A. A brief history of hepatitis C. HCV advocate, Hepatitis C Support Project. 2015.

3. Safi S Z, Badshah Y, Waheed Y, Tahir S, Fatima K, Shinwari A et al. Distribution of hepatitis $\mathbf{C}$ virus genotypes, hepatic steatosis and their correlation with clinical and virological parameters in Pakistan. Asi. Biomedi. 2010; 4: 253-262.

4. Abbas S, Ali Z M, Muhammad A H, Shaw S, Abbas S $\mathrm{Q}$. Frequency of $\mathrm{HCV}$ infection and its genotypes among patients attending a liver clinic and voluntary blood donors in a rural area of Pakistan. Pak. J. Med. Sci. 2009; 4: 579-582.

5. Idrees M, Riazuddin S. Frequency distribution of hepatitis $\mathbf{C}$ virus genotypes in different geographical regions of Pakistan and their possible routes of transmission. BMC Infect. Dis.2008; 8: 62-69.

6. Choo Q L, Kuo G, Weiner A J, Overby L R, Bradley B W, Houghton M. 1989. Isolation of a cDNA clone derived from a blood-borne non-A, non-B viral hepatitis genome. Science. 1989; 244:359-62.

7. Safi S Z, Badshah Y, Waheed Y, Tahir S, Fatima K, Shinwari A, Qadri I. Distribution of hepatitis C virus genotypes, hepatic steatosis and their correlation with clinical and virological parameters in Pakistan. Asi. Biomedi. 2010; 4: 253-262.

8. Qadri I, Iwahashi M, Capasso J M, Hopken M W, Flores $\mathrm{S}$, Schaack J. Induced oxidative stress and activated expression of manganese superoxide dismutase during hepatitis $\mathbf{C}$ virus replication: Role of JNK, p38 MAPK and AP-1. Biochem. J. 2004; 378: 919-928. 
9. Jacobson I M, Davis G L, Serag E L, Negro H, Trépo F C. Prevalence and challenges of liver diseases in patients with chronic hepatitis $\mathbf{C}$ virus infection. Clin. Gastroenterol. Hepatol. 2010; 8: 924-933.

10. Qadri I, Iwahashi M, Kullak-Ublick G A, Simon F R. Hepatocyte nuclear factor (HNF) 1 and HNF4 mediate hepatic multidrug resistance protein 2 Upregulation during hepatitis $\mathbf{C}$ virus gene expression. Mol. Pharmacol. 2006; 70: 627-636.

11. Guo J, Yan R, Xu G, Li W, Zheng C. Construction of the Vero cell culture system that can produce infectious HCV particles. Mol. Biol. Rep. 2007; 36: 111-120.

12. Gupte P, Dudhade A, Desai H G. Acquired apolipoprotein B deficiency with chronic hepatitis C virus infection. Indian. J. Gastroenterol. 2006; 25: 311-312.

13. Yoon $E \mathrm{~J}, \mathrm{Hu} K \mathrm{~K}$. Hepatitis $\mathbf{C}$ virus (HCV) infection and hepatic steatosis. Int. J. Med. Sci. 2006; 3: 53-56.

14. Bosch F X, Ribes J, Diaz M, Cleries R. Primary liver cancer: Worldwide incidence and trends. Gastroenterol. 2004; 127: 5-16.

15. Sharma N K, Sherker A H. Epidemiology, risk factors, and natural history of chronic hepatitis C. In: Shetty K, Wu GY, eds. Clinical gastroenterology: chronic viral hepatitis. New York: Humana Press. 2009; 33-70.

16. Namazee N, Sali S, Asadi S, Shafiei M, Behnava B, Alavian S M. Real response to therapy in chronic hepatitis $\mathbf{C}$ virus patients: A study from Iran. Hepat. Mon. 2012; 12: 61-51.

17. Wenhong Z, Dazhi Z, Xiaoguang D, Qing X, Jiajii J, et al. Consensus on pegylated interferon alpha in treatment of chronic hepatitis B. J Clin Transl Hepatol. 2018; 28; 6(1): 1-10.
18. Jose L W, Gutierrez J A, Elllman W B, Stump D D, Keller T R, Rodriguez. Profiles of substitutions in hepatitis $C$ virus RNA of the core, alternate reading frame, and NS2 coding regions. RNA. 2002; 8: 557-571.

19. Farhana M, Hussain I, Haroon T S. Hepatitis C: The dermatologic profile. J. Pak. Assoc. Derm. 2009; 18: 171-81.

20. Rauf A. Nadeem M S, Ali A, lqbal M, Mustafa M, Latif M M, Latif M Z, Ahmed N, Shakoori A. Prevalence of hepatitis $B$ and $C$ in internally displaced persons of war against terrorism in Swat, Pakistan. Eur J Public Health. 2011 ; 21 : 638-642.

21. Messina J P, Humphreys I, Flaxman A, Brown A, Cooke G S, Pybus O G. Global distribution and prevalence of hepatitis C virus genotypes. Hepatol. 2015; 61:7787.

22. Lontok E, Harrington $P$, Howe A, Kieffer T, Lennerstrand $\mathrm{J}$, Lenz $\mathrm{O}$, et al. Hepatitis $\mathbf{C}$ virus drug resistanceassociated substitutions: State of the art summary. Hepatology. 2015; 62: 1623-1632.

23. Niu Z, Zhang P, Tong Y. Age and gender distribution of Hepatitis $\mathbf{C}$ virus prevalence and genotypes of individuals of physical examination in Wu Han, Central China. Springerplus. 2016; 13; 5(1):1557.

24. Mindikoglu A L, Miller R R. Hepatitis $\mathbf{C}$ in the elderly: Epidemiology, natural history, and treatment. Clin Gastroenterol Hepatol. 2009; 7(2):128-34.

25. Idrees $M$, Riazuddin S. Frequency distribution of hepatitis $\mathbf{C}$ virus genotypes in different geographical regions of Pakistan and their possible routes of transmission. BMC Infect. Dis. 2008; 8: 62-69.

\begin{tabular}{|c|c|c|c|}
\hline \multicolumn{4}{|c|}{ AUTHORSHIP AND CONTRIBUTION DECLARATION } \\
\hline Sr. \# & Author-s Full Name & Contribution to the paper & Author's Signature \\
\hline 1 & Nighat Aslam & Article write up, data analysis. & ivat \\
\hline 2 & Khalid Nadeem Asif & $\begin{array}{l}\text { Data collection, Lab } \\
\text { experiments. }\end{array}$ & uleid \\
\hline 3 & Sadia Zafar & $\begin{array}{l}\text { Data collection, Lab } \\
\text { experiments. }\end{array}$ & Sadier \\
\hline 4 & Amer Jamil & Supervisor. & \\
\hline
\end{tabular}

